\title{
Reversing the Malthusian paradigm on retirement age
}

\author{
PATRICK DEBOOSERE ${ }^{1}$ \\ HADEWIJCH VANDENHEEDE ${ }^{1}$
}

\begin{abstract}
Résumé
La démographie a toujours influencé la pensée politique. La décision récente d'augmenter l'âge à la pension dans beaucoup de pays développés est inspirée par l'évolution importante de la composition par âge de la population. Mais il y a en réalité peu d'arguments pour augmenter l'âge à la retraite si l'on tient compte de l'ensemble des données démographiques et économiques. Une interprétation souvent trop simpliste et même parfois erronée d'indicateurs démographiques contribue à cette démarche. L'utilisation systématique d'indicateurs démographiques dans la discussion sur la viabilité du système des pensions et de la sécurité sociale est selon nous souvent inspirée par la théorie de l'économie de l'offre. Un aspect crucial est le fait que la croissance de la productivité est ignorée ou minimisée. À cet égard, la discussion actuelle présente une profonde similitude avec l'approche Malthusienne de la population.
\end{abstract}

\section{Mots clés}

Vieillissement de la population, espérance de vie, paradigme Malthusien, taux de dépendance.

\section{Abstract}

Demography always influenced political thinking. The recent decision to increase the age of retirement in many high-income countries is driven by a dramatic change in the age composition of the population. We argue that there is in fact no need to increase the age of retirement and that many aspects of the current evolution both in demography and in economy are overlooked. Moreover, some demographic indicators such as life expectancy or the dependency ratio are often interpreted in a simplistic and erroneous way. The systematic use of demographic indicators to discuss the sustainability of the pension system and of the social security system is in our view often inspired by the supply-side way of economic thinking. A crucial aspect is that productivity increase is ignored or minimalized in the discussion. In this regard the discussion has many similarities with the Malthusian approach of the population question.

1. Vrije Universiteit Brussel, Vakgroep voor Sociologie, Interface Demography. 


\section{Keywords}

Population aging, life expectancy, Malthusian paradigm, dependency ratio.

In the past 100 years, life expectancy of Belgian men increased by 28 years (49 to 77) and that of Belgian women by 30 years (53 to 83) (HMD). In a much shorter time frame - since 1950 -, life expectancy worldwide increased by no less than 22 years, from 46 to 68 years (United Nations, 2013). The mortality decline is by any standard one of the most important achievements of mankind. But instead of praising this development, we ended up fearing it. Press articles and politicians talk about it not as a success story, but as a problem: the spectre of ageing populations. And one of the main conclusions is that «as we live longer, we will have to work longer».

Why do we need to work longer? The idea is based on two arguments. First, we, as a society, cannot afford to pay for so many unproductive persons. A crude demographic indicator, the dependency ratio, underpins this first argument. The second reasoning is slightly different. It is based on the observation that most people are indeed living longer than their parents. As we are living longer, why should we not work longer? The idea is based on the interpretation of another demographic indicator: life expectancy.

Demography is thus at the core of one of the main societal discussions of our time: the revision of our social security system and, more generally, the relationship between work and income. In our opinion, this discussion is flawed, because it is largely fuelled by two wrong ideas. The first misleading idea is associated with the spectacular growth in life expectancy at birth, which creates the incorrect perception, even among demographers, that the human species is conquering immortality and is no longer ageing. The second wrong idea is on the ineluctability of demographic processes and their inevitable consequences, the so-called TINA option («there is no alternative»). Demography is one of the factors changing our societies and creating new challenges. But the solutions we choose are based on political choices and we can follow many different strategies to cope with these new challenges. Much too often the demographic fact is presented as having inevitable implications, leaving no other options open.

In this paper we will briefly develop five points. Firstly, we will evaluate the spectacular increase in life expectancy over the past century. Secondly, we will discuss the implications of this increase for the future evolution of life expectancy. Thirdly, we will address the question of the 
sustainability of ageing populations. In a fourth point, we link the question of sustainability to that of the mandatory retirement age. A final section reflects on the relation between demography and politics. Each of these points would deserve a more in-depth discussion, but the aim of this paper is to link these together to illustrate how the interpretation of demographic indicators has influenced the political agenda.

\section{Are we really living longer?}

\section{Evolution in life expectancy versus length of human life span}

Many people are convinced that humans are becoming increasingly old. An often-heard example to support this conviction is that the seventyyear-old of today is the sixty-year-old of half a century ago. And indeed, the probability of dying at age 70 today in Belgium dropped to the probability of dying at age 60 thirty years ago ${ }^{2}$. Yet, the probability of dying is not quite the same as the process of ageing. The revolution of our time is not in an alteration of the ageing process, but that modern societies control far better all risk factors for premature death and, hence, create the opportunity for each of us to reach the «normal» age characteristic of the human species' biological clock.

The progress in life expectancy creates in the public at large a belief, propagated by some scientists (de Grey, 2005) ${ }^{3}$, that we are at the verge of achieving immortality and that we are no longer ageing - the ideology of the forever young. From a psychological point of view, this belief is a strong argument to accept the fact that in the long run we will have to work longer (van Solinge, Henkens, 2010). In a milder and less extreme version, the following statement is often repeated: that, compared to fif-

2. This shift in equivalent mortality rates to older ages is also compressed by age. Observation over a century shows that 87-year-olds in 2010 have the same mortality rate as the 77-year-olds in 1910, the 94-year-olds in 2010 compare to the 87-year-olds in 1910 and the 99-year-olds to the 94-year-olds.

3. Most prominent among these scientists is Aubrey de Grey and his SENS (Strategies for Engineered Negligible Senescence) Research Foundation. Although sharply criticised by other scientists, de Grey received large media coverage, including in Belgium. One of the most extreme among these scientists is computer scientist Ray Kurzweil, hired by Google to lead Calico, a life science start-up. Kurzweil's ambition is to achieve eternal life. Without going that far, National Geographic recently published a cover story «This baby will live to be 120» (May, 2013), claiming: «It's not just hype. New science could lead to very long lives». 
ty years ago, people are living much longer when they retire. This is then illustrated by the fact that male life expectancy in 1960 was about 67 years and is 77 years today. Next, the need for raising the retirement age is directly linked to this evolution in life expectancy, asserting that at the moment of the introduction of the repartition system life expectancy at birth was 65 years, whereas it is 80 years nowadays, and that the current repartition system is thus untenable (Peersman, Schoors, 2012).

The conclusion that we are living so much longer is based on a wrong interpretation of the concept of life expectancy. The spectacular growth in life expectancy at birth has fundamentally distorted popular and scientific beliefs about changes in longevity and health, including those of demographers. In 1910, male life expectancy in Belgium at age 65 was 11 years; now it is 17 years. At age 85, male life expectancy was 3.5 years; now it is 5.3 years. We have clearly arrived at a point where the limits of old-age mortality have shifted towards a higher level, thanks to improved living conditions over the life course and to more efficient medical interventions. Yet, as a species we are not living that much longer. Although life expectancy at birth, the average length of life, was in all probability considerably lower in all past human history, this cannot be said of human lifespan. Long lifespans have been typical of most humans since the late Middle Pleistocene (O'Connell et al., 1999).

Different hypotheses try to explain these long (post-reproductive) lifespans in humans in terms of evolutionary advantages, since it is now generally accepted that the length of the human lifespan is not genetically programmed. Given the inevitability of death, living organisms have to replicate and thus to adapt to their environmental conditions as to optimize reproduction (O'Connell et al., 1999). Carey and Judge (2001) explicitly exclude the existence of a species-specific fixed lifespan and consider lifespan as a life-history adaptation. In the past 100'000 years, our species has only known some small genetic modifications, allowing for diversified adaptation to the starkly divergent environments we have been living in. These small mutations explain divergence in human phenotypes, but not changes in humans' fundamental cell metabolism, their typical lifespan and reproductive cycle.

The acceptance that the length of the human lifespan is not genetically programmed does however not change the observation that «while bodies are not designed to fail, neither are they designed for extended operation» (Carnes, Olshansky, 2007). The limits of longevity (the length of the human lifespan) have to be understood as the result of the probabilistic outcome "of the stochastic components of senescence» (Finch, 
Kirkwood, 2000). Moreover, evolutionary aspects of longevity are in fact of little relevance for explaining the rise in life expectancy of the last 100 years.

\section{Explanations for the recent rise in life expectancy}

There is still discussion on the precise mechanisms that eventually led to a rise in life expectancy. Yet, there is general agreement on the central role of scientific progress and technology, causing a surge in economic productivity and resulting in improved living standards. Regular access to high-calorie foods, improved sanitation, and a more efficient medical approach (vaccines, antibiotics, surgical interventions, etc.) have all been credited as contributors. The result has been a massive decline in premature mortality, with a shift from infectious to chronic diseases as the main causes of death. This process has been coined the «epidemiological transition» by Abdel Omran (Omran, 1971). The recent progress in old-age survival is moving human longevity to a new frontier (Kannisto, 1994). This spurred several new discussions on the existence of a fixed lifespan, on the potential of healthy ageing or the compression of morbidity (Cheung, Robine, 2007; Fries, 1980; Fries, 2005b; Manton et al., 1999), and on the changing human body (Floud et al., 2011).

Epigenetics is one of the theoretical paths developed in recent years to explain increased longevity (Gentilini et al., 2013). According to this theory, DNA remains unchanged but is modulated by biochemical signals. One of the processes involved is methylation, in which methyl groups attach themselves at the outside of the gene and change its responsiveness to biochemical signals. Diet and exercise are considered processes that could impact the methylation process. This process could explain the fact that, given our genetic predisposition, we can push the frontiers of health, at least at the individual level, but it does neither change the basic facts of life and death, nor the genetic information we will pass on to our children (Pagel, 2012; Stringer, 2011).

What has often been overlooked in the process towards a higher life expectancy is the fact that all members of society have benefited from this process. Increasing life expectancy is first and foremost a social phenomenon: it is the outcome of a collective process where the chances to live longer are distributed more evenly (or «shared») across the population. Nowadays almost every child can live upon an older adult age and more than $90 \%$ of a birth cohort in Europe will live beyond the age of 65 , as illustrated by the evolution of the survival curves for Belgium between 1910 and 2010 (Figure 1). As an indicator of average years to 
live, life expectancy is only marginally influenced by the oldest age groups, and depends heavily on how many newborns survive until a reasonably old age. In this respect, life expectancy is a product of science and technology, but also of human solidarity. The strong increase in life expectancy from the 1880s onwards is intrinsically linked to the emergence of the labour movement, the introduction of social laws, and the development of a social security system. It is the result of the implementation of technological progress in better living conditions and the fact that these improvements have been accessible for all. Our pension system is a keystone of our social security system. Its contribution to wellbeing and health is difficult to quantify, but the impact can surely not be underestimated, as $40 \%$ of the population declares to be in less than good health at age 60 (Deboosere et al., 2006). Allowing people to retire when work becomes mentally and physically too demanding is highly likely to add some extra years of healthy survival.

FIGURE 1 Survival curves of Belgian women 1910-2010

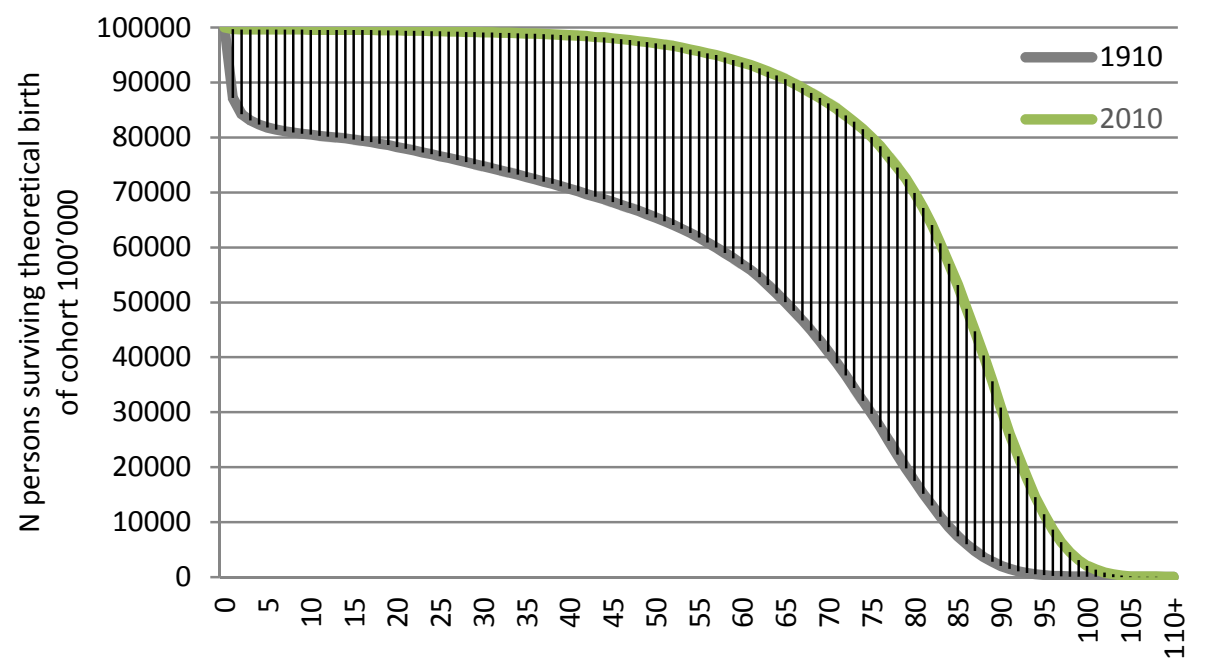

Age 
FIgURE 2 Belgian men - age-specific contribution to the increase in life expectancy ${ }^{4}$

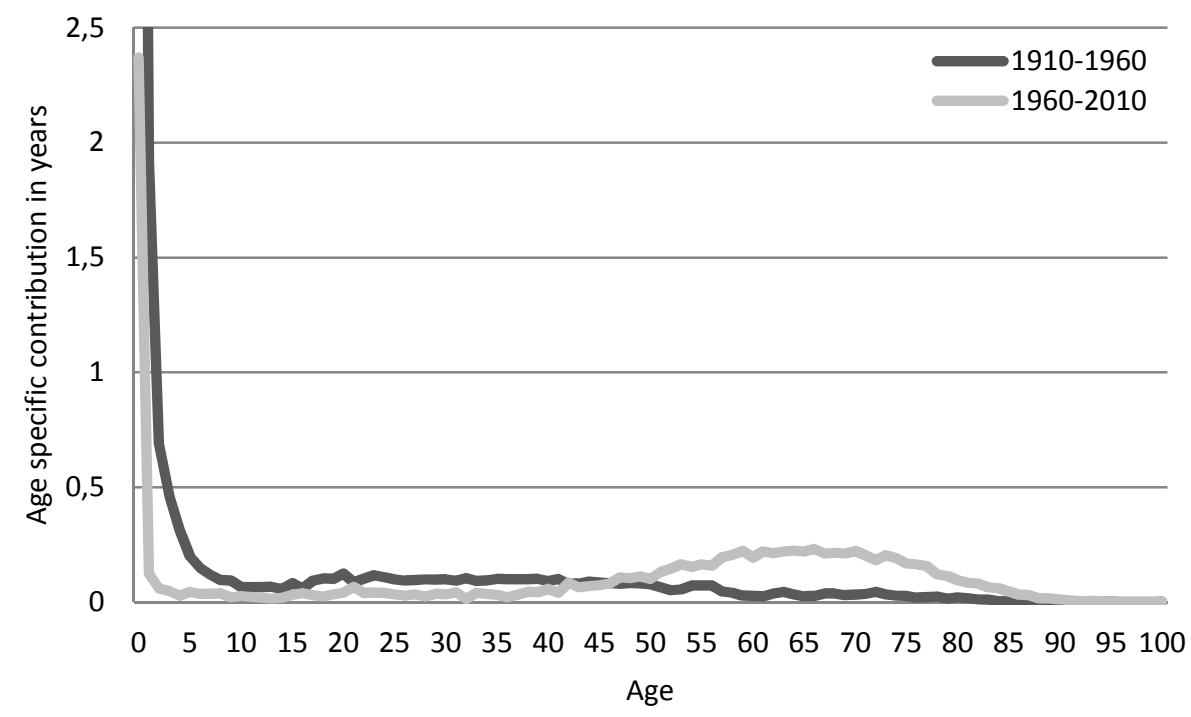

Data: Human Mortality Database.

A decomposition of the gains in life expectancy by age (Arriaga, 1984) demonstrates that $42 \%$ of the increase in life expectancy in Belgian men between 1910 and 1960 was due to a decrease in infant mortality (Figure 2). By contrast, in the same period life expectancy at 65 increased by 1 year only: from 11 years in 1910 to 12.3 years in 1960 . Still, the total gain in life expectancy at birth was an impressive 27.7 years. In the period 1960-2010, life expectancy continued to increase, but at a slower rate than in the period 1910-1960: 10.7 years of life expectancy were added, instead of 27.7 in the first period. $50 \%$ of this progress took place below the age of 5, mainly in the period before 1985. In 1985, life expectancy in Belgian men aged 65 reached 13.3 years. Compared to 1960, 65-year-old Belgian men could expect to live one additional year. In 2010, life expectancy at age 65 was 17.5 years, an increase of 4.2 years compared to 1985. This latter evolution implies an important shift in the pattern of mortality reduction, from mortality reductions in the young to mortality reductions in the elderly. In the last 25 years, more gains in life expectancy among men aged 65+ have been made than in the preceding 75 years. This overall pattern demonstrates furthermore that the

4. $\quad+17$ years in 1910-1960 \& +10.7 years in 1960-2010; y-axis not fully shown as contribution under age 1 is more than 8 years for the $1910-1960$ period. 
shift of falling mortality rates in the young and adult population towards older adults is slowing down the progress in life expectancy in the countries with the highest life expectancy. Life expectancy at birth has risen more slowly in the last decades than before (Bongaarts, 2006), and in most countries there is a decline in its average increase from decade to decade (de Beer, 2006).

\section{What does this imply for the future evolution of life expectancy?}

Recently, the Netherlands Interdisciplinary Demographic Institute (NIDI) made life expectancy projections based on the assumption that life expectancy will continue to increase at the same rate as in the past: per annum, 0.3 years of life expectancy would be gained (de Beer, 2013). Based on this assumption, at least $50 \%$ of all girls born today would live to be a 100, with life expectancy for women being 96 years. This line of thinking is based inter alia on the article by Jim Oeppen and James Vaupel, who concluded that «For 160 years, best-performance life expectancy has steadily increased by a quarter of a year per year, an extraordinary constancy of human achievement» (Oeppen, Vaupel, 2002). However, these authors are slightly more prudent than de Beer by specifying that «an alternative method for forecasting life expectancy is to analyze the rapidity of improvement in age-specific death rates over many decades and then to use this information to project death rates over coming decades» (idem, p. 1'031). Using this approach, one arrives at considerably lower increases in life expectancy, as the factors responsible for the steady annual increase in life expectancy of the past are no longer present. Using the extrapolation method of life expectancy based on life expectancy increase in the last hundred years results in a life expectancy of 102 years for Belgian men in 2100. If the extrapolation method is applied on a decrease in age specific death rates similar to the past hundred years life expectancy of Belgian men will reach 86 years in 2100 (i.e. the current life expectancy of Japanese women).

The reason for this difference lies in the properties of life expectancy as measure of mortality. Life expectancy is first and foremost a collective process. It is a social construct that measures to what extent a society is able to optimize the biological potential of the human species in an as long as possible life for all of its members. Increasing life expectancy is the result of improvements in the probability of surviving at all ages and for all members of a society. Each year added to the total number of years lived by each birth cohort improves the outcome. Yet, a first ele- 
ment to bear in mind is that the survival of a young person adds more to the increase in life expectancy than the survival of an older person. In the calculation of life expectancy, the survival of a baby during the first year of its life equals the gain in life expectancy of eighty eighty-yearolds surviving one additional year. Hence, once mortality has dropped to extremely low levels at young and adult ages, it becomes increasingly difficult to realize further progress in life expectancy. Under the unrealistic hypothesis of a decrease to zero mortality for all persons under the age of 65, life expectancy of Belgian men and women can only increase by about 4.5 years.

The «easy» wins have been spent and increasing life expectancy has to be realised in the older age groups. This is not impossible, but extending survival time in older age groups is simply more difficult because of the laws of nature. As mentioned above, we did not change the basics of cell metabolism nor did we improve organ renewal in the human body. The best we can do for now is repairing some ailing parts. Heart surgeries, joint replacements, cataract operations, etc. are all wonderful interventions, pushing the rectangularisation of the survival curve into the oldest old. This «manufactured survival time» (Olshansky, Carnes, 2001) is even adding some quality of life to old age, but the ageing process of the human body does not stop, ineluctably ending up in frailty and death. There is some elasticity to this ageing process: a healthier lifestyle creates more opportunities for healthier ageing (Fries, 2005a). Yet, even the rich and powerful do not transgress the natural laws.

These biological constraints are translated in the entropy of the life table (Olshansky, Carnes, 2001): «with improvement in mortality everyone dies at about the same age, and a proportional improvement in mortality at all ages makes less and less difference in the expectation of life» (Keyfitz, Caswell, 2005). There is no reason to impose an upper limit on life expectancy, as centenarians and super centenarians empirically prove that there is plenty of room for further progress. Still, it is not realistic that the per annum increase in life expectancy of the past fifty years will continue at the same rate in the next fifty years. Life expectancy will continue to increase in the future, but even the more realistic scenario, based on lowering age-specific mortality rates in the next decades at the same rate as in the past, becomes increasingly difficult. It implies continuous and considerable progress in living conditions and in medical interventions, pushing the individual's survival age upwards and dissipating this progress to all members of society; life expectancy is after all a collective process. 
If we assume that age-specific mortality rates decline at the same rate as in the past 100 years, the increase in life expectancy in Belgium will at best be 0.1 year per annum in the next 100 years (own calculations). This is in line with the estimates of the United Nations Population Division. For all developed regions of the world, the UN estimates that systematic progress against mortality will lead to a further increase of life expectancy by 0.13 years per annum, resulting in an actual life expectancy at birth of 88.9 years in 2100 (United Nations, 2013).

The ageing of a population is the result of more ageing individuals: surviving longer, maybe healthier, but not escaping ageing. We marginally gain manufactured life in old ages, but with decreasing elasticity. Faster increases will need spectacular scientific breakthroughs (Vallin, Meslé, 2010). As a retiree, one can count on a few years more, but not on adding an extra dozen years, and that will remain so in the near future. An additional question in this regard is how healthy these extra years will be. The debate on the expansion versus compression of morbidity related to an increased life expectancy started at the end of the seventies (Fries, 1980), and empirical research is still on going (Crimmins, Saito, 2001; Jagger, Robine, 2011). Although there is some evidence that increases in life expectancy and in population health are narrowly intertwined, more uncertainty exists about the progress in health of the oldest old (Van Oyen et al., 2008). What is certain however - and very relevant when discussing the age of retirement -, is the fact that healthy life expectancy is extremely unevenly spread in the population according to socio-economic status. Calculations for Belgium reveal a difference in healthy life expectancy of 10 years between higher educated and primary educated men. While higher educated men have a healthy life expectancy of 71.3 years, it is 61.6 years in men with only primary education (Van Oyen et al., 2011).

There is no reason to believe that progress in life expectancy will stop at a certain threshold, but a realistic forecast about the progress that can be realized in the near future assumes this to be relatively modest. The frontier of human lifespan is empirically fixed at 122 years, the record lifespan observed and fully documented (Maier et al., 2010). This record has been unbroken for 18 years, and it will stand for some more years, given the age of the oldest living people. That the current record will be broken is certain, as the number of super centenarians in the world is growing, However it is unclear when, and the estimates of the time needed to break this record demonstrate how near we are to the frontiers of the human lifespan (Wilmoth, Ouellette, 2011). What we have been changing until now is the mean age of death, not its maximum. 
Changes in this mean age of death do have an impact on the proportion of elderly in a population, with important economic consequences, an issue we will discuss in detail in part 3 and 4.

The conclusion is clear: it is highly unlikely that age-specific mortality will decrease much faster in the future than in the past, unless spectacular breakthroughs in genetic engineering and medical interventions, with a direct impact on the ageing process, take place. The corollary of this conclusion is that the proportion of $65+$ and $85+$ will continue to increase in the near future, but that the prospect of unlimited ageing is an illusion. Of course, countries with a long history of below-replacement fertility will, in absence of international immigration, end up with a high proportion of persons aged 65 and more. In a population with replacement fertility, population ageing will be more modest and the proportion of 65-year-olds will not exceed $30 \%$ in the next century (Commission, 2014; Uhlenberg, 2009).

\section{Is an ageing population sustainable?}

This brings us to the following question: can we support a population with $30 \%$ aged 65 or older? From a strictly theoretical point of view, this does not present a problem. Looking at the past, our wealth has increased substantially, while the number of working hours per person decreased dramatically. The key is productivity increase, and there is no reason to assume that our technological innovation will be halted in the future. We could use part of our future productivity increases to support higher pension costs. If we assume human ingenuity to continue extending human life, why could productivity not follow at the same pace?

Still, using the demographic dependency ratio, it is often argued that we will have to postpone retirement age in order to be able to pay for future pensions and to preserve the social security system «for our children». The evolution of the dependency ratio and more particularly the old-age dependency ratio has indeed left many arguing that the relationship between the active population and the elderly dependent population is not sustainable in the long run (Oeppen, Vaupel, 2002).

In Belgium, the cost of future ageing has been quantified. In 2001, the Study Committee on Ageing, established within the High Council of Finance, was created in order to monitor the rising costs linked to population ageing. The Committee is commissioned with drawing up an annual report on the budgetary and social consequences of ageing up to 2060 . 
The cost of ageing can be defined as the difference in budgetary transfers for social expenses due to the change in population composition by age. Table 1 reproduces the synthetic table of the 2014 annual report of the Committee (Comité d'Étude sur le Vieillissement, 2014).

TABLE 1 Reprint of the synthetic table of the 2014 report of the Study Committee on Ageing

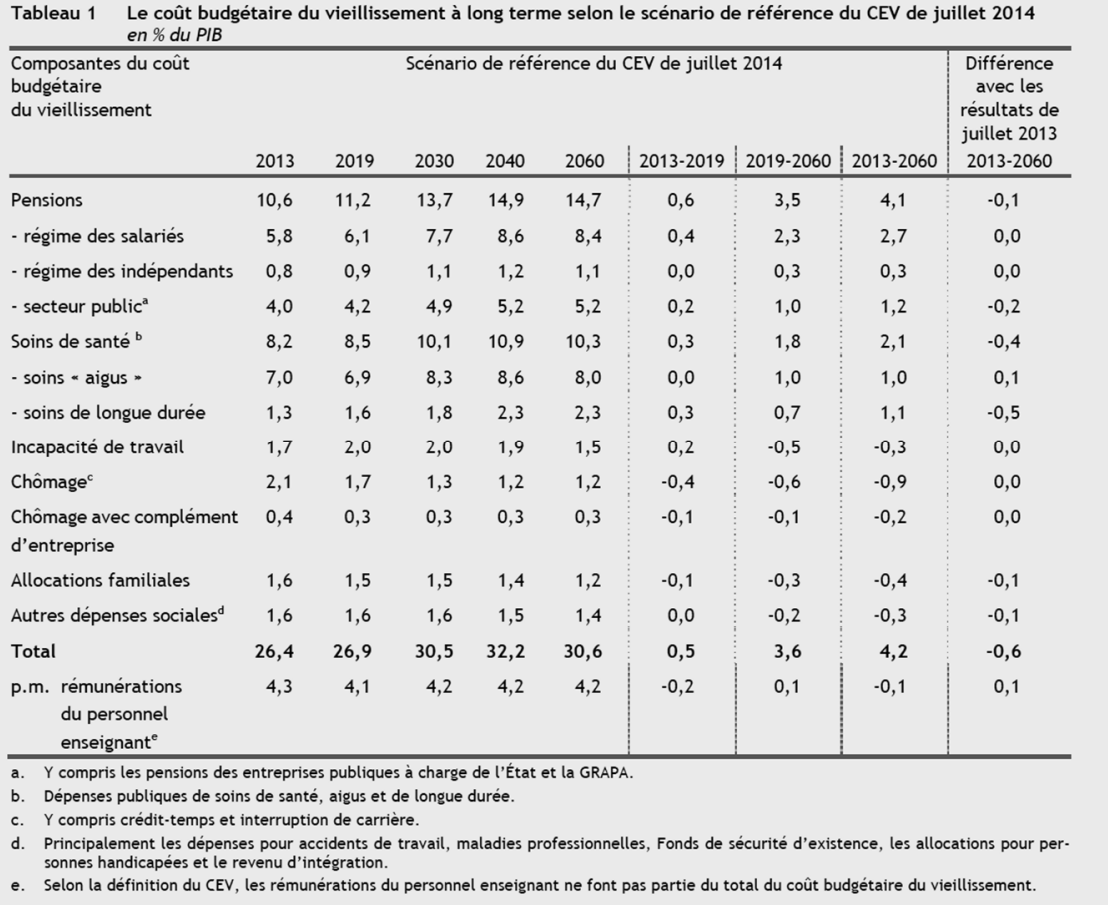

Source: Comité d’Étude sur le Vieillissement, 2014.

The 2014 annual report predicts that the cost of ageing will increase over the period $2013-2060$ to a total of $4.2 \%$ of GDP in 2060 , a yearly increase of social expenses due to ageing of less than $0.1 \%$ over a period of almost 50 years. Recently, we have been hit by the banking crisis of 2008. The effect of the crisis increased the expenses for social security in a single year with an estimated 3\% of GDP (Comité d'Étude sur le Vieilissement, 2011). Of course, this crisis is making a balanced budget more difficult, but it also puts the ageing cost in perspective. The banking crisis of 2008 did make our social expenses soar overnight with more than half of the expected cost of ageing. (We are not even taking 
into account the additional billions used by the Belgian government to save the banks).

However, the most overlooked fact in this debate is the yearly increase of GDP as such. If we adopt the central assumption of the Study Committee on Ageing, which assumes an increase in productivity of $1.5 \%$, we will double our purchasing power over the next fifty years ${ }^{5}$. What will we do with this additional wealth? Will we buy twice as many cars, build houses twice as big? Of course, there are still many other investments that can be made; however, the potential wealth created is, all things being equal, grossly underestimated when only the relative increase of the cost of ageing is taken into account. Doubling our GDP in the future will leave plenty of room for spending a few more percentages to sustain an elderly population.

To simplify the data of the Study Group on Aging, 26 euros of the 100 euros of wealth produced in Belgium today is used to sustain its social security system (including expenses for pensions, for unemployment, for all kinds of allowances, and for health), with 74 euros going to all other needs (Comité d'Étude sur le Vieillissement, 2014). The cost of ageing will make our social security system much more expensive in the future. In fact, fifty years from now we will need 62 euros to sustain the system instead of the 26 euros today (Comité d'Étude sur le Vieillissement, 2014). Yet, the wealth to be produced will, all things being equal, have doubled to 200 euros; hence, the future generation will have 138 euros to spend on other needs, instead of the 74 euros today.

The future increase - in the next 40 years or so - of the share of the population above age 65 is comparable to the increase in dependent person-years since the crisis of 1973. Indeed, when, instead of using the demographic dependency ratio, real age at retirement, unemployment and the average number of years Belgian youth is studying longer are taken into account, we end up with a completely different, more sustainnable picture. Additional years of education are a good investment, but are also proof of how increased economic dependency was sustainable, because it was accompanied by increased welfare. In all industrialized countries, the share of young adults in the labour force has been declining much faster than the share of young adults in the population. The mean age of entry into Belgium's labour force increased by about 5

5. The Study Committee on Ageing uses the increase in productivity to estimate annual economic growth. With a yearly increase of 1.5\%, GDP will double in exactly 46 years. If we adopt the most pessimistic scenario of the Study Committee on Ageing, which estimates the annual increase to be $1.25 \%$, the doubling time of GDP will be 56 years. 
years over the past 50 years (own calculations based on census data). The result has been a sharp decline in labour participation of young adults. The share in the labour force of men and women aged 20 to 24 dropped from 13.9\% in 1983 (first available data) to $7.4 \%$ in 2013. When adjusting for the declining population share of this age group, this represents a decline in labour force participation of 35\% over 30 years (OECD, 2015). Consequently, in recent years several demographers claimed that the dependency ratio has been incorrectly interpreted, and insisted on the need to use more meaningful indicators when addressing economic questions (Deboosere et al., 2009; Lee, Mason, 2010; Rada, 2013).

If we take the capital accumulation (in buildings, infrastructure and social capital) of the past and the gains in productivity of the future into account, we can perfectly support the social security system. We have already done so in the past. The history of Europe in the past hundred years, notwithstanding wars and the major crisis of the thirties, has been one of constant progress in the welfare system, accompanied by a secular reduction in the number of hours worked.

\section{Why insist on the need to increase the mandatory retirement age?}

When carefully analysing the annual reports of the Study Committee on Ageing (Comité d'Étude sur le Vieillissement, 2013), one wonders why some economists insist on the need to increase the mandatory retirement age (Wided, 2014); all the more so since the banking crisis of 2008 evolved into a large unemployment crisis. The stubbornness of maintaining this line of thinking in a time of towering unemployment levels in Europe suggests a strong ideological blindness. It hints towards a logic trapped into the dominant economic thinking of «supply sides economics». From a conceptual point of view, there seems to be a clear correlation between the TINA approach of working longer and the plea for tax cuts and fiscal austerity (Blyth, 2012; Council of the European Union, 2002; Freyssinet, 2004). The austerity approach to the crisis is in fact very similar to the answer on how to tackle the cost of ageing populations. This approach is rooted in a profound misunderstanding of the current crisis. The main point is that the triggers of the crisis are mixed up with its deeper roots. Among the many triggers, deregulation, greed of the banking sector or the housing bubble are often put forward, and indeed played a major role in provoking and feeding the crisis; but the real problem of the crisis, its deeper roots, suggests a classic example of 
«overproduction». The combination of too many highly productive workers and too few consumers creates a stalled economy. This does not at all imply that there are no needs anymore. Still, low incomes and unemployment are not the best incentives for demand. The huge accumulation of richness in the hands of a very small group cannot substitute the demand for consumer goods. Quite the contrary, the increased income inequality and highly skewed wealth distribution add instability to the system, with huge amounts of capital in search of higher returns on investment (Galbraith, 2012; Spector, 2012). Keynes predicted in 1930 that there would be a «fifteen-hour week» in 2030 - the ultimate outcome of the increase in productivity (Keynes, 1963). He was surely overly optimistic and underestimated how technological and scientific progress would increase the demand for work, but the core of his thinking, a better redistribution of work and income, appears to be the only long-term solution.

The argument of a «lack of labour force» - very popular in the retirement debate before 2008 - has now completely disappeared from the discussion on ageing. Insisting on «working longer» has become particularly insane in a Europe with millions of unemployed. Belgium has done relatively well compared to other countries. Still, the Belgian unemployment rate in 2013 was either $8 \%$ or $12.1 \%$, depending on the data source used (European Union based on the Labour Force Sample Survey or administrative data respectively). The insistence on the need to increase the mandatory retirement age reveals what it always has been: merely an operation to slash pension costs. In the Belgian context, it is difficult to explain the added value or the economic rationality of increasing the mandatory retirement age with 2 years, when the mean age at retirement is 60 years and when more than half a million persons are unemployed. An increase of the retirement age with two years implies that more than $300^{\prime} 000$ additional workplaces have to be created. The National Bank of Belgium forecasts a maximum creation of 59'000 jobs over the next five years (National Bank of Belgium, 2014), a figure largely contested by the Federal Planning Bureau. Yet, the economists of the Federal Planning Bureau do accept job creation in the long run based on the hypothesis that growth is induced through supply of labour (Bureau fédéral du Plan, 2015). 


\section{The role of demography}

In hindsight, modern demography has been extremely powerful in framing the need of «structural reforms», which has served mainly as «a code phrase for deregulation» (Krugman, 2013) and for slashing social security by presenting reforms as a demographic imperative.

It is instructive to look at the historical parallel with Robert Malthus, a typical protagonist of apocalyptic demography. Malthus is well known because of his population theory, but his work was used in the first place to abolish the Poor Laws in the UK. The origin of the English Poor Laws goes back to the 14th century and was codified at the end of the 16th century. It was conceived against beggars and migrant vagabonds, but installed a system of parish-based relief for the poor. The Poor Law was extremely important in times of bad harvest to help the poorest farmers. Malthus considered that the Poor Law subsidised marriage between paupers and for English industrialists the Poor Law retained too many impoverished farmers in the countryside. Malthus argued that the Poor Law contributed to maintaining poverty. We probably underestimate that it was «his perversity thesis that arguably changed the course of history [...] converting the poor from a structural position to a behavioral choice» (Somers, Block, 2005).

Population ageing worldwide is the only possible demographic outcome of the end of world population growth. Longevity and lower fertility are changing the classic population pyramid into a population rectangle. Yet, it is not because the demographic outcome is inevitable that there is only one possible societal answer. The future of mankind is inextricably linked to the end of population growth and, perhaps even more so, to our ability to change extensive economic growth into sustainable growth rather than unilaterally increasing GDP through export and competition.

Some people may wish to work longer, because they feel the need to keep busy or because they enjoy the social contacts. Yet, we cannot confuse a question of choice with a question of need. To impose work on the elderly as a condition to have an income is shameful and economically counterproductive; it will not solve any problems in modern societies, only create more. There is of course room for discussion about the optimal retirement age in any given society. Yet, facts point to the urgent need to rethink work and income distributions in the modern economies of today rather than to increase the retirement age. The impact of information technology and robotics has only started to change manu- 
facturing. This evolution will not stop and each hour of labour input will produce an increasing amount of output. Of course, output will shift towards more sophisticated products and our new production mode will need more highly skilled workers. The fundamental challenge within this new economic paradigm however will be to create an inclusive society (OECD, 2014). In the meantime, we have to make the right choices in reorienting our economy and our production process towards low-carbon technologies (IPCC, 2014). Provided that we make the right choices, we now have the opportunity to change society for the better while improving life for all, to the benefit of both this and the next generation. An early retirement age and more free time for working-age adults are available options. Although this requires a fundamental rethinking of taxation policies, as it runs against the widespread «anti-taxation» ideology.

Malthus has proved to be fundamentally wrong about the fact that technology and human inventiveness could tackle his «natural law», i.e. the tendency of all animated life to replicate itself beyond the means available for its subsistence. In this regard, the challenge of ageing populations is very similar. For much of the apocalyptic demography (or economy!) today, the error in reasoning is even worse. Indeed, if we believe that medical progress can further increase life expectancy in the future, why should technological innovation and productivity not be able to match this progress?

The Malthusian paradigm makes it hard to admit that we have to work less to enjoy the fruits of our labour. Our analysis calls for a reversal of the paradigm: we are living longer, because we are working less during our lifetime and do so in much better conditions.

\section{Reference}

ARRIAGA E. (1984), "Measuring and Explaining the Change in Life Expectancies», Demography, 21, pp. 83-96, http://dx.doi.org/10.2307/2061029.

BLyth M. (2012), Austerity: The History of a Dangerous Idea, Oxford, Oxford University Press.

BongaARTs J. (2006), "How Long Will We Live?», Working Paper Population Council, (215), 33 p.

Bureau fédéral du Plan (2015), Les impacts économiques et budgétaires de long terme des réformes structurelles décidées par le gouvernement Michel, Février, Brussels, $14 \mathrm{p}$. 
CAREY J. R., Judge D. S. (2001), "Life Span Extension in Humans Is Self-Reinforcing: A General Theory of Longevity», Population and Development Review, 27 (3), pp. 411-436.

Carnes B. A., Olshansky J. S. (2007), "A Realist View of Aging, Mortality, and Future Longevity", Population and Development Review, 33 (2), pp. 367-81, http://dx.doi. org/10.1111/j.1728-4457.2007.00172.x.

Cheung S. L. K., Robine J.-M. (2007), «Increase in Common Longevity and the Compression of Mortality: The Case of Japan», Population Studies, 61 (1), pp. 85-97, http://dx.doi.org/10.1080/00324720601103833.

Comité d'Étude sur le Vieilissement (2011), Rapport annuel, Brussels, Conseil Supérieur des Finances, $83 \mathrm{p}$.

Comité d’Étude sur le Vieillissement (2013), Rapport annuel, Brussels, Conseil Supérieur des Finances, $97 \mathrm{p}$.

Comité d'Étude sur le Vieillissement (2014), Rapport annuel, Brussels, Conseil Supérieur des Finances, $68 \mathrm{p}$.

Council of the European Union (2002), Increasing Labour-Force Participation and Promoting Active Ageing, Brussels, Council of the European Union.

Crimmins E. M., SAITo Y. (2001), "Trends in Healthy Life Expectancy in the United States, 1970-1990: Gender, Racial and Educational Differences», Social Science \& Medicine, 52 (11), pp. 1'629-1'641.

DE BEER J. (2006), "Future Trends in Life Expectancies in the European Union», Research Note, Brussels, European Commission, 9 p.

DE BEER J. (2013), «Een levensduur van meer dan honderd jaar: van uitzondering naar regel?», NIDI-Webartikel, Accessed okt 2013.

DE Grey A. (2005), «Resistance to Debate on how to Postpone Ageing is Delaying Progress and Costing Lives. Open Discussions in the Biogerontology Community Would Attract Public Interest and Influence Funding Policy», EMBO, 6 (Spec No), pp. S49-S53, http://dx.doi.org/10.1038/sj.embor.7400399.

Deboosere P., Lammens L., Surkyn J. (2009), «De goocheltruc met de afhankelijkheidsratio of een pleidooi voor het invoeren van een onderhoudscoëfficiënt», $B$. CANTILlon, K. VAN DEN BosCh, S. Lefebure (eds), Ouderen in Vlaanderen en Europa, Tussen vermogen en afhankelijkheid, Leuven, Acco, pp. 19-52.

Deboosere P. et al. (2006), Santé et soins informels, Enquête socio-économique 2001 monographies, 1; Brussels, Politique Scientifique Fédérale.

European Commission (2014), The 2015 Ageing Report, Underlying Assumptions and Projection Methodologies, European Economy Series, Brussels, European Commission, $413 \mathrm{p}$.

FINCH C. E., KIRKWOOD T. B. (2000), Chance, Development, and Aging, Oxford, Oxford University Press. 
Floud R. et al. (2011), The Changing Body. Health, Nutrition, and Human Development in the Western World since 1700, Cambridge, Cambridge University Press, http://dx.doi.org/10.1017/CBO9780511975912.

Freyssinet J. (2004), "Taux de chômage ou taux d'emploi, retour sur les objectifs européens», Travail, Genre et Sociétés, 11, pp. 109-120, http://dx.doi.org/10.3917/ tgs.011.0109.

FrIES J. F. (1980), «Aging, Natural Death, and the Compression of Morbidity», The New Engalnd Journal of Medicine, 303 (3), pp. 130-135, http://dx.doi.org/10.1056/ NEJM198007173030304.

FrIES J. F. (2005a), «Frailty, Heart Disease, and Stroke: The Compression of Morbidity Paradigm", American Journal of Preventive Medicine, 29 (5 Suppl 1), pp. 164-168, http://dx.doi.org/10. 1016/j.amepre.2005.07.004.

FrIES J. F. (2005b), "The Compression of Morbidity», The Milbank Quarterly, 83 (4), pp. 801-823, http://dx.doi.org/10.1111/j.1468-0009.2005.00401.x.

GalbraItH J. (2012), Inequality and Instability. A Study of the World Economy just Before the Great Crisis, Oxford, Oxford University Press, 324 p., http://dx.doi.org/ 10.1093/acprof:osobl/9780199855650.001.0001.

GeNTILINI D. et al. (2013), «Role of Epigenetics in Human Aging and Longevity: Genome-Wide DNA Methylation Profile in Centenarians and Centenarians' Offspring», Age (Dordr), 35 (5), pp. 1'961-1'973.

Hall S. S. (2013), "This Baby Will Live to Be 120», National Geographic, 223(5), May. HMD (2015), «Human Mortality Database University of California, Berkeley (USA), and Max Planck Institute for Demographic Research (Germany)», www.mortality. org, Accessed May 2015.

IPCC (2014), Climate Change 2014: Impacts, Adaptation, and Vulnerability, Cambridge, Cambridge University Press, 1'132 p.

JAgger C., Robine J.-M. (2011), "Healthy Life Expectancy», R. Rogers, E. CRIMmins (eds), International Handbook of Adult Mortality, New York, Springer, pp. 551-568, http://dx.doi.org/10.1007/978-90-481-9996-9_26.

KANNISTo V. (1994), «Development of Oldest-Old Mortality, 1950-1990: Evidence from 28 Developed Countries», Odense, Odense University Press.

Keyfitz N., Caswell H. (2005), Applied Mathematical Demography, Third edition, New York, Springer, $555 \mathrm{p}$.

Keynes J. M. (1963), «Economic Possibilities for our Grandchildren», Essays in Persuasion (1930), New York, W. W. Norton \& Co, pp. 358-373.

Krugman P. (2013), «The Plot Against France», New York Times, Sec. International Opinion. 
Lee R., Mason A. (2010), "Some Macroeconomic Aspects of Global Population Aging», Demography, 47 (Supplement), pp. S151-S172, http://dx.doi.org/10.1353/ dem.2010.0002.

MAIER H. et al. (2010), Supercentenarians, Editions Springer, A series of the Max Planck Institute for Demographic Research, Berlin Heidelberg.

Manton K., Stallard E., Corder L. (1999), "The Limits of Longevity and their Implications for Health and Mortality in Developed Countries», J. CHAMIE, R. L. CLIQUET (eds), Health and Mortality Issues of Global Concern. Proceedings of the symposium health and mortality, Brussels, United Nations, $467 \mathrm{p}$.

National Bank of Belgium (2014), Economic Review June 2014, Brussels, 142 p.

O’Connell J. F., HaWkes K., BluRton Jones N. G. (1999), "Grandmothering and the Evolution of Homo Erectus», Journal of Human Evolution, 36 (5), pp.461-485, http://dx.doi.org/10.1006/jhev.1998.0285.

OECD (2014), All-on-Board-Making-Inclusive-Growth-Happen, 202 p.

OECD (2015), OECD Stat (database), stats.oecd.org online database, 8 March.

Oeppen J., Vaupel J. W. (2002), "Demography. Broken limits to life expectancy», Science, 296 (5'570), pp. 1'029-1'031.

Olshansky J.S., CARnes B.A. (2001), The Quest for Immortality, Science at the Frontiers of Aging,New York, W. W. Norton.

OMran A. R. (1971), "The Epidemiologic Transition. A Theory of the Epidemiology of Population Change», Milbank Mem Fund Q, 49 (4), pp. 509-538, http://dx.doi. org/10.2307/3349375.

Pagel M. (2012), Wired for Culture. The Natural History of Human Cooperation, London, Penguin Books.

Peersman G., Schoors K. (2012), De perfecte storm. Hoe de economische crisis de wereld overviel en vooral: hoe we eruit geraken, Gent, Borgerhoff \& Lamberigts, $236 \mathrm{p}$.

RADA C. (2013), "Population Ageing and its Global Challenges», S. MCDANIEL, Z. ZIMMER (eds), Global Ageing in the Twenty-First Century: Challenges, Opportunities and Implications, Surrey, Ashgate, pp. 159-173.

Somers M. R., BLock F. (2005), «From Poverty to Perversity: Ideas, Markets, and Institutions over 200 Years of Welfare Debate», American Sociological Review, 70 (2), pp. 260-287, http://dx.doi.org/10.1177/000312240507000204.

SPECTOR A. (2012), «The Origins and Development of the Global Capitalist Economy and Capitalist Crises», B. Berberoglu (ed), Beyond the Global Capitalist Crisis, Burlington, Ashgate, pp. 17-33.

StRINGeR C. (2011), The Origin of Our Species, London, Penguin Books, 333 p.

Uhlenberg P. (2009), International Handbook of Population Aging, 1, New York, Springer, 769 p., http://dx.doi.org/10.1007/978-1-4020-8356-3. 
United Nations (2013), World Population Prospects, The 2012 Revision, I, New York, $439 \mathrm{p}$.

Valuin J., Meslé F. (2010), «Espérance de vie : peut-on gagner trois mois par an indéfinitiment ?», Population \& Sociétés, (473), 4.

VAN OYEN H. et al. (2008), "Trends in Health Expectancy Indicators in the Older Adult Population in Belgium between 1997 and 2004», European Journal of Ageing, 5 (2), pp. 137-146, http://dx.doi.org/10.1007/s10433-008-0082-8.

VAN OYEN H. et al. (2011), "Contribution of Mortality and Disability to the Secular Trend in Health Inequality at the Turn of Century in Belgium», European Journal of Public Health, 21 (6), pp. 781-781, http://dx.doi.org/10.1093/eurpub/ckq198.

VAN Solinge H., HeNKens K. (2010), "Living Longer, Working Longer? The Impact of Subjective Life Expectancy on Retirement Intentions and Behaviour», Eur J Public Health, 20 (1), pp. 47-51, http://dx.doi.org/10.1093/eurpub/ckp118.

WIDED B. (2014), «De inzet van de verkiezingen 2014: Het stilzwijgen van de partijen over pensioenen moet doorbroken worden», Knack.

Wilmoth J. R., Ouellette N. (2011), «Maximum Human Lifespan: Will the Records be Unbroken?», European Population Conference, Stockholm. 